\title{
ANALISIS DAN PERANCANGAN SISTEM PENAGIHAN PEMBAYARAN UNIT LOKASI PADA PT. KITITA ALAMI DI BANDARJAYA PLAZA LAMPUNG TENGAH
}

\author{
Wina Aprini* ${ }^{1}$ \\ ${ }^{* 1}$ Program Studi Sistem Informasi \\ Fakultas Ilmu Komputer \\ Universitas Bandar Lampung \\ Jl. Zainal Abidin Pagar Alam No. 26 \\ Labuhan Ratu Bandar Lampung 35142
}

\begin{abstract}
PT Kitita Alami merupakan perusahaan swasta nasional yang usahanya bergerak dibidang jasa developer dan kontraktor. Saat ini PT Kitita Alami mendapat kepercayaan dari Pemerintah Daerah Lampung Tengah untuk merevitalisasi pasar tradisional Bandarjaya menjadi pasar dengan fasilitas moderen, yang kini bernama Bandarjaya Plaza. Dalam hal ini, produk yang dipasarkan oleh PT Kitita Alami berupa unit usaha berdagang, seperti ruko, toko, kios maupun los. Ada beberapa cara yang diterapkan untuk memasarkan unit usahanya kepada calon pedagang yang berminat memiliki lokasi berdagang di Bandarjaya Plaza, yaitu sistem penjualan secara tunai dan kredit. Adapun sistem pengolahan data, laporan dan informasi pada PT Kitita Alami masih dilakukan secara semi komputerisasi, proses pengolahan data belum terprogram menyeluruh, pencatatan buku besar (berkas) masih menggunakan program aplikasi Microsoft Word dan pengolahan data penjumlahan menggunkan program aplikasi Microsoft Excel. Sistem tersebut kurang efektif, akan mengakibatkan resiko-resiko yang tidak diinginkan seperti kesalahan pencatatan, dan keterlambatan laporan, maka diperlukan sistem baru yang mampu mengolah data pemesanan unit usaha. Sehingga dapat memberikan suatu informasi yang lebih akurat, efektif dan efisien dan dapat mencapai hasil kerja yang berkualitas tinggi sesuai dengan target yang diinginkan.

Keywords : Program Aplikasi ,Informasi, Sistem Informasi .
\end{abstract}

\section{PENDAULUAN}

Ilmu pengetahuan dan teknologi sangat berperan dalam menunjang aktivitas kerja diberbagai bidang. Kemajuan teknologi berdampak pada semua aspek kehidupan manusia yang berhubungan dengan dunia informasi dan teknologi. Salah satu bentuk perkembangan teknologi adalah komputer. Komputer sangat berperan dalam penyajian informasi yang tepat, akurat dan lebih aman. Komputer sangat potensial untuk dijadikan sarana pengembangan teknologi informasi yang lebih baik bersamaan dengan permintaan dan kebutuhan dalam proses memperoleh informasi yang dibutuhkan. Informasi dibutuhkan oleh pihak instansi atau perusahaan dalam mengambil suatu keputusan yang tepat untuk mengatur manajemennya. Informasi yang berkualitas akan berpengaruh dalam modus kerja di suatu instansi atau perusahaan.

PT Kitita Alami selaku pengembang Bandarjaya Plaza, yang merupakan satu-satunya pasar tradisional dengan fasilitas moderen dan terbesar di Lampung Tengah. Dalam hal ini, produk yang dipasarkan oleh PT Kitita Alami berupa unit usaha berdagang, seperti ruko, toko, kios maupun los. Bandarjaya Plaza terletak di Jln. Proklamator Ruko No.1 Bandarjaya Plaza Lampung Tengah. Ada beberapa cara yang diterapkan untuk memasarkan unit usahanya kepada calon pedagang yang berminat memiliki lokasi berdagang di Bandarjaya Plaza, yaitu sistem penjualan secara tunai dan kredit. Dan saat ini Bandarjaya Plaza lebih memfokuskan pada pembangunan Revitalisasi Pasar khususnya Pasar Tradisional di dalam pelaksanaannya perusahaan ini mendapatkan usahanya melalui tender proyek.

Sistem yang ada masih dilakukan secara semi komputerisasi, proses pengolahan data belum terprogram menyeluruh, pencatatan buku besar (berkas) masih menggunakan program aplikasi Microsoft Word dan pengolahan data penjumlahan menggunkan program aplikasi Microsoft Excel. Sistem tersebut kurang efektif, akan 
mengakibatkan resiko-resiko yang tidak diinginkan seperti kesalahan pencatatan, dan keterlambatan laporan, maka diperlukan sistem baru yang mampu mengolah data pemesanan unit usaha. Sehingga dapat memberikan suatu informasi yang lebih akurat, efektif dan efisien serta dapat mencapai hasil kerja yang berkualitas tinggi sesuai dengan target yang diinginkan.

\section{a. Perumusan Masalah}

Berdasarkan latar belakang di atas, maka permasalahan dalam penelitian ini adalah bagaimanakah pengelolaan masalah pelayanan informasi, jumlah penjualan, keterlambatan / tunggakan bayaran serta pembuatan laporan, sebagai pengganti dari sistem yang lama.

\section{b. Batasan Masalah}

Sistem dibuat hanya membahas masalah yang berhubungan dengan pembayaran unit lokasi secara kredit, dan informasi jumlah penjualan, keterlambatan/tunggakan bayaran serta pembuatan laporan, sebagai pengganti dari sistem yang lama.

\section{c. Metode Pengumpulan Data}

- Wawancara

- Pengamatan

\section{d. Metode Pengembangan Sistem}

Metode pengembangan system yang digunakan pada penelitian ini adalah sebagai berikut:

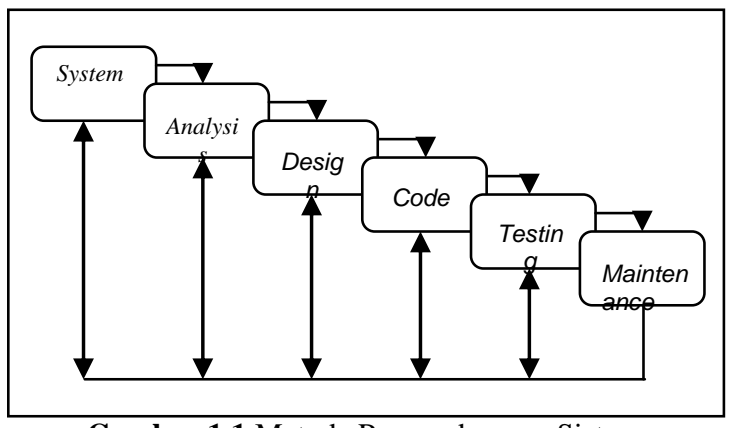

Gambar 1.1 Metode Pengembangan Sistem

\section{LANDASAN TEORI}

\section{a. Pengertian Sistem}

Menurut Jogiyanto, H.M (2001:2) Sistem adalah kumpulan dari elemen-elemen yang berinteraksi untuk mencapai suatu tujuan tertentu.
Sistem menurut Mulyadi (2001:2) adalah "sekelompok unsur yang erat berhubungan satu dengan yang lainnya, yang berfungsi bersamasama untuk mencapai suatu tujuan tertentu. Jadi sistem adalah satu kesatuan dari beberapa elemen yang saling berinteraksi untuk mencapai tujuan tertentu".

Sistem pada dasarnya adalah suatu kerangka atau kelompok unsur yang saling berhubungan erat satu dengan yang lainnya, disusun sesuai dangan suatu bentuk yang menyeluruh dan berfungsi bersama-sama untuk mencapai tujuan tertentu. Sistem diciptakan untuk menangani proses yang berulangkali atau secara rutin terjadi. Setiap sistem terdiri dari suatu proses, struktur sistem merupakan unsur-unsur yang membentuk sistem tersbut. Sedangkan proses sistem menjelaskan cara kerja setiap unsur sistem tersebut dalam mencapai tujuan sistem. Setiap sistem merupakan bagian dari sistem lain yang lebih besar disebut supra sistem dan terdiri dari beberapa sistem disebut subsistem. Pengertian tersebut dapat disimpulkan bahwa sistem merupakan suatu ruang kerja yang terdiri dari komponen-komponen yang saling berinteraksi atau berhubungan satu sama lain untuk mencapai tujuan tertentu.

\section{b. Karakteristik Sistem}

Menurut Jogiyanto (2001:3) suatu sistem mempunyai karakteristik atau sifat-sifat tertentu :

1. Komponen Sistem (Component)

Suatu sistem terdiri dari jumlah komponen yang saling berinteraksi, membentuk suatu kesatuan.

2. Batasan sistem (Boundary)

Merupakan daerah yang membatasi antara suatu sistem dengan sistem yang lainnya atau dengan lingkungan luarnya.

3. Lingkungan Luar Sistem (Environment) Suatu sistem yang ada diluar batas sistem dan mempengaruhi operasi sistem.

4. Penghubung Sistem (Interface) Merupakan media penghubung antara satu subsistem dengan subsistem yang lainnya.

5. Masukan Sistem (Input)

Merupak energi yang dimasukkan ke dalam sistem berupa perawatan (maintenance input) dan masukan signal (signal input).

6. Keluaran Sistem (Output) 
Merupakan sustu energi atau bahan yang diolah dan diklasifikasikan menjadi keluaran dan berguna dan sisa pembuangan.

7. Pengolahan Sistem (Process System)

Suatu sistem dapat mempunyai suatu bagian pengolah yang akan merubah masukan menjadi keluaran.

8. Sasaran Sistem (Objective System)

Suatu sistem pasti mempunyai tujuan (goal) atau sasaran (objective), yaitu agar dapat tercapainya cara kerja atau kinerja yang efektif dan fisien.

\section{c. Pengertian Data}

Menurut Fathansyah (2002:2) data adalah "representasi fakta dunia nyata yang mewakili suatu objek seperti manusia (pegawai, siswa, pembeli, pelanggan, barang, hewan, peristiwa, konsep, keadaan, dan sebagainya), yang direkam dalam bentuk angka, huruf, simbol, teks, gambar, bunyi, atau kombinasinya".

\section{d. Basis Data}

Basis data (Database) adalah suatu susunan atau kumpulan data operasional lengkap dari suatu organisasi atau perusahaan yang diorganisir atau dikelola dan disimpan secara terintegrasi atau terhubung dengan menggunakan metode tertentu menggunakan komputer sehingga mampu menyediakan informasi optimal yang diperlukan pemakainya. Sedangkan sistem basis data adalah suatu sistem menyusun dan mengelola recordrecord menggunakan komputer untuk menyimpan atau merekam serta memelihara data operasional sebuah perusahaan sehingga mampu menyediakan informasi yang optimal guna pengambilan keputusan.

\section{e. Siklus Informasi}

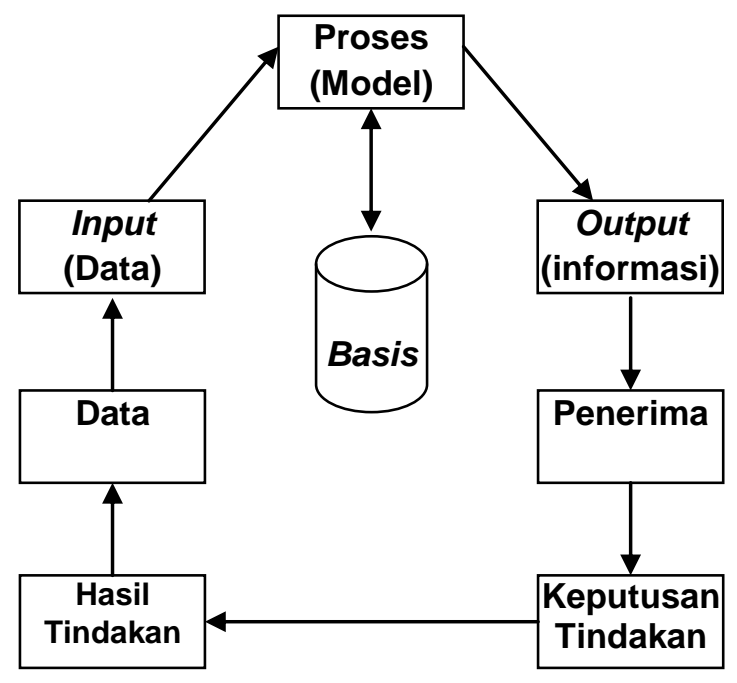

Gambar 2.1 Siklus Informasi

\section{f. Pengertian Kredit}

Pengertian penjualan kredit menurut Mulyadi (2001) adalah "penjualan suatu barang atau jasa yang tidak langsung menghasilkan kas, tetapi menimbulkan piutang yang dalam jangka waktu tertentu piutang tersebut akan terealisasi menjadi kas".

\section{g. Entity Relationship Diagram (ERD)}

Entity Relationship Diagram (ERD) adalah kumpulan suatu model jaringan kerja yang mendeskripsikan hubungan antara penyimpanan dalam DFD, karena itu ERD berbeda dengan DFD. Dengan ERD kita dapat menguji dengan mengabaikan proses yang harus dilakukan. Tujuan utama dari penggambaran ERD adalah menunjukkan objek-objek data (entity) dan relationship yang ada pada objek-objek tersebut.

\section{h. Diagram Alir Data (Data Flow Diagram)}

Data Flow Diagram (DFD) adalah suatu network yang menggambarkan suatu sistem komputerisasi, manualisasi atau gabungan dari keduanya, yang penggambarannya disusun dalam bentuk kumpulan komponen sistem yang saling berhubungan sesuai dengan aturan mainnya. DFD digunakan untuk menggambarkan suatu sistem yang telah ada atau sistem baru yang akan dikembangkan secara logika tanpa mempertimbangkan lingkungan fisik dimana data tersebut mengalir dan akan disimpan. DFD juga dapat menggambarkan arus data di dalam sistem dengan terstruktur dan jelas.

\section{i. Kamus Data}


Kamus data adalah sekumpulan elemenelemen atau simbol-simbol yang digunakan untuk membantu dalam menggambarkan atau mengidentifikasikan setiap field-field atau file di dalam sistem.

Normalisasi adalah suatu teknik yang menstrukturkan data dalam cara-cara tertentu untuk membantu atau mencegah timbulnya masalah yang berhubungan dengan data dalam basis data.

Kunci yang digunakan dalam normalisasi antara lain :

1. Calon Kunci (Candidate Key)

Atribut di dalamnya relasi yang biasanya mempunyai nilai unik.

2. Kunci Alternatif (Alternatif Key)

Kunci kandidat yang tidak terpakai sebagai Primary Key atau atribut untuk menggantikan kunci utama

3. Kunci Utama (Primary Key)

Candidate Key yang dipilih untuk mengidentifikasikan tuple secara unik dalam relasi.

4. Kunci Tamu (Foreign Key)

Aribut dengan domain yang sama yang menjadi kunci utama sebuah relasi, tetapi pada relasi lain atribut tersebut hanya sebagai atribut biasa.

\section{j. Proyek dalam Visual basic}

Berikut ini adalah tampilan proyek didalam Visual Basic:

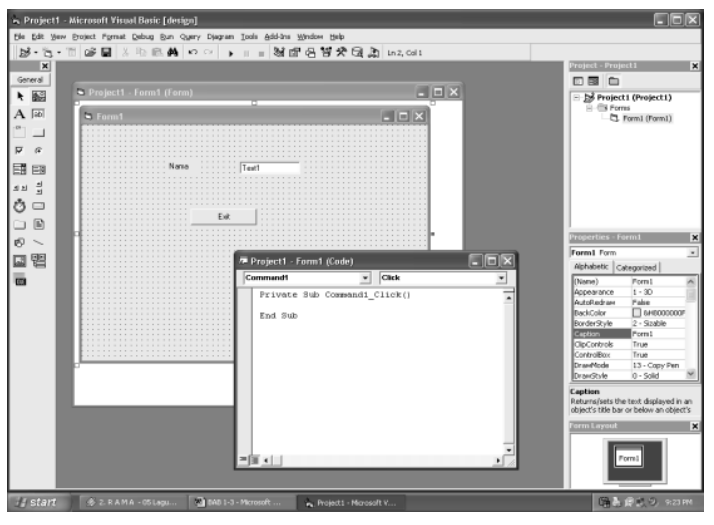

Gambar 2.2 Proyek Dalam Visual Basic

\section{k. Tampilan Microsoft Visual Basic 6.0}

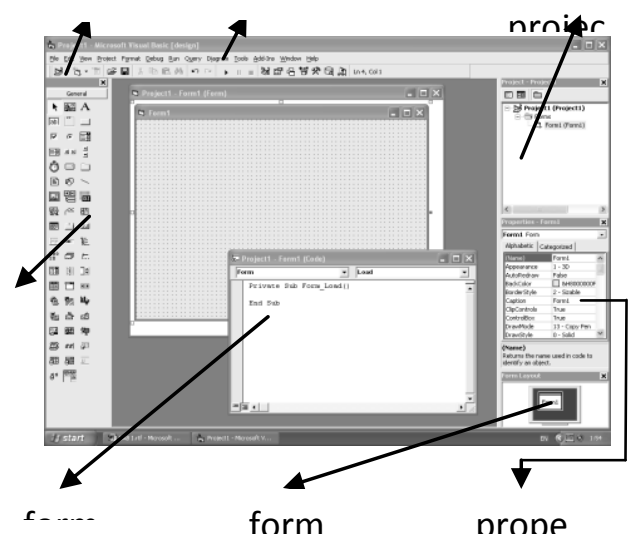

Gambar 2.3 Tampilan Visual Basic 6.0

\section{l. Microsoft Access 2003}

"Microsoft Access 2003 merupakan salah satu program pengolahan data base yang mengolah berbagai jenis data dengan pengoprasian yang mudah. Dengan Microsoft Access kita dapat melakukan proses penyortiran, pengaturan data, pembuatan table data serta pembuatan laporan kegiatan sehari-hari." (Andi $2000: 3)$

\section{METODE PENELITIAN}

\section{b. Metode pengumpulan data}

Metode pengumpulan data pada penelitian ini dilakukan dengan cara wawancara dan pengamatan.

\section{c. Analisis data}

\section{Entity Relationsip Diagram (ERD)}

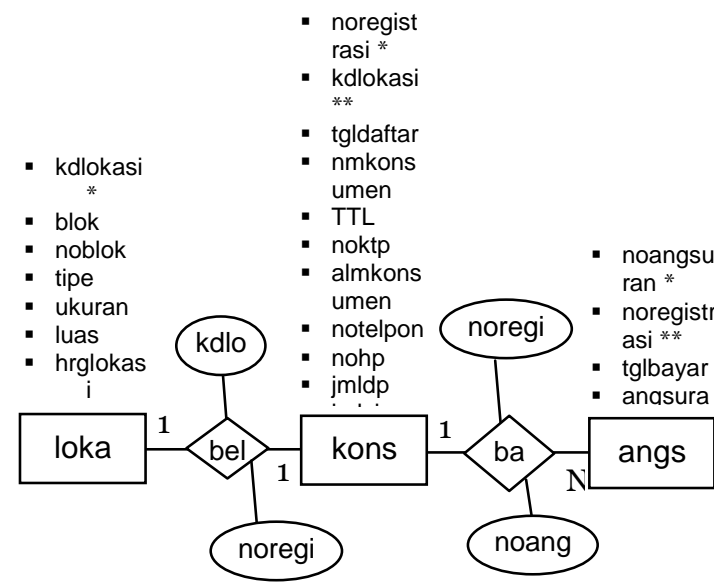

Keterangan:

* $\quad$ : Primary key (kunci utama) 


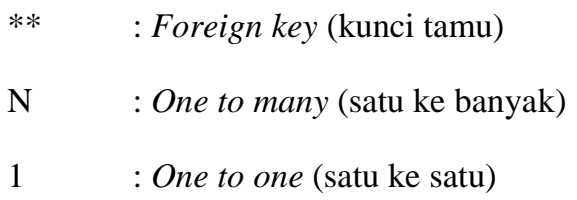

\section{d. Perancangan Sistem}

\section{Rancangan Masuk}

Berikut ini adalah tampilan dari rancangan antarmuka Halaman Masuk:

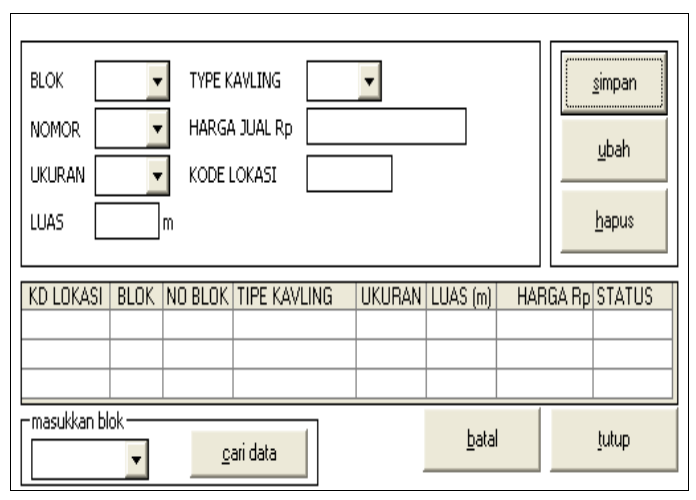

Gambar 3.1 Rancangan Antarmuka Halaman Masuk

\section{Rancangan Output Laporan Data Konsumen}

Berikut ini adalah tampilan dari rancangan antarmuka Halaman Output Laporan Data Konsumen:

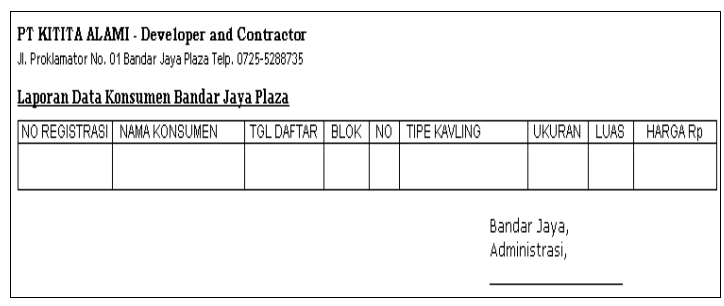

Gambar 3.2 Rancangan Antarmuka Halaman Output Laporan Data Konsumen

\section{Rancangan Output Laporan Data Pembayaran}

Berikut ini adalah tampilan dari rancangan antarmuka Halaman Output Laporan Data Pembayaran:

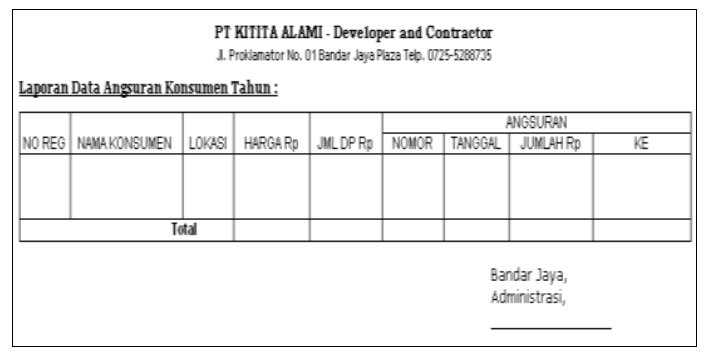

Gambar 3.3 Rancangan Antarmuka Halaman Output Laporan Data Pembayaran

\section{Rancangan Menu Aplikasi}

Berikut ini adalah rancangan menu aplikasi:

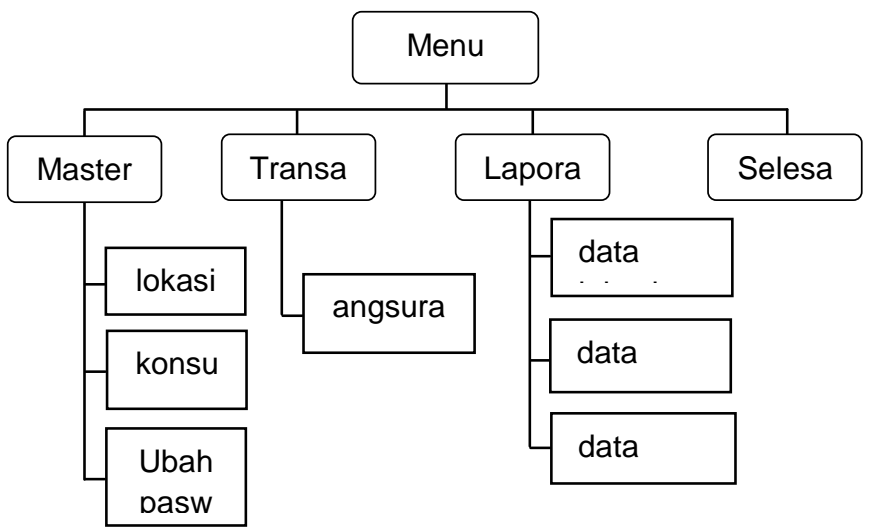

Gambar 3.4 Diagram Rancangan Menu Aplikasi

\section{Flowchart Menu Utama}

Berikut ini adalah Flowchart yang menggambarkan kegiatan di Menu Utama. 


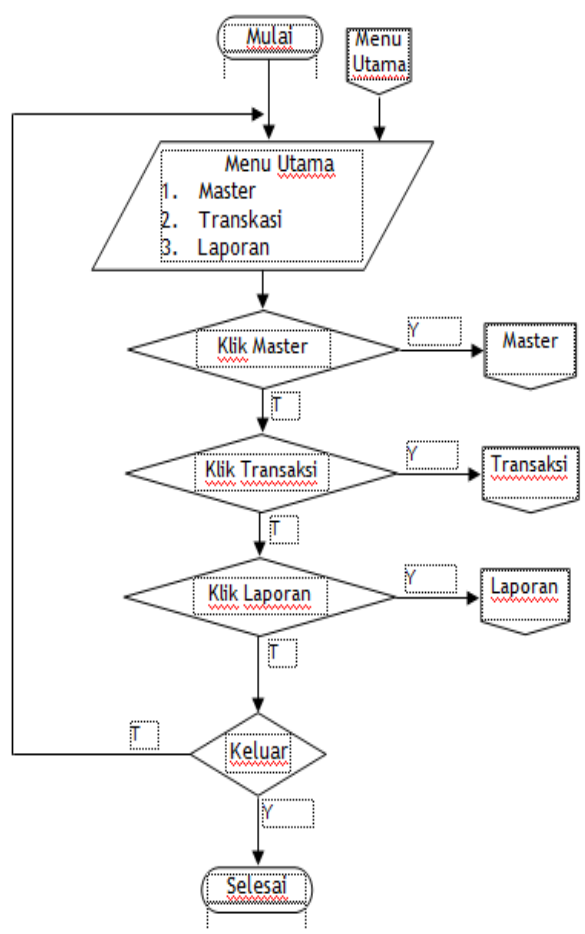

Gambar 3.5 Flowchart Menu Utama

\section{Flowcart Submenu Transaksi}

Berikut ini adalah Flowchart yang menggambarkan kegiatan di Submenu Transaksi.

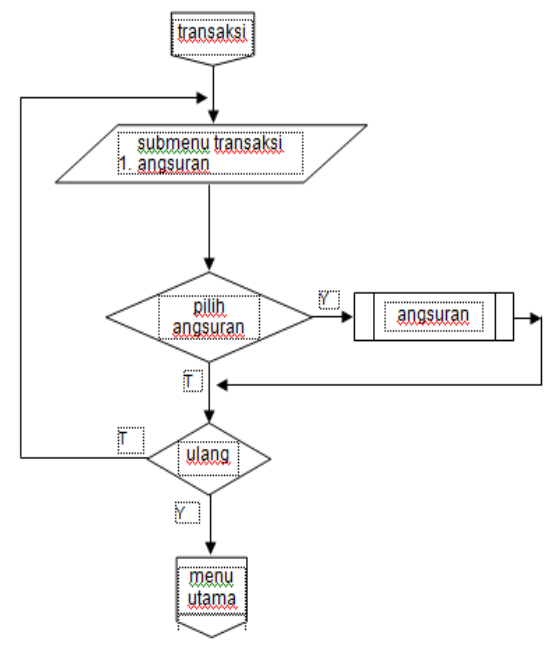

Gambar 3.6 Flowchart Submenu Kegiatan

\section{Perangkat Keras Sistem yang diusulkan}

Perangkat keras yang digunakan pada program aplikasi ini mempunyai spesifikasi minimal sebagai berikut.

a) Processor Intel P3 733; b) VGA $16 \mathrm{MB}$;

c) RAM $128 \mathrm{MB}$;

d) Harddisk $20 \mathrm{~GB}$;

e) SVGA monitor 15';

f) CD room;

g) Keyboard dan mouse standar;

h) Printer standar.

Spesifikasi hardware di atas merupakan spesifikasi standar yang digunakan penulis, penggunaan hardwrare di bawah spesifikasi di atas dapat mengakibatkan program aplikasi tidak berjalan optimal.

\section{e. Implementasi Sistem}

\section{Password}

Saat pertama dijalankan, program aplikasi ini menampilkan password seperti gambar berikut ini.

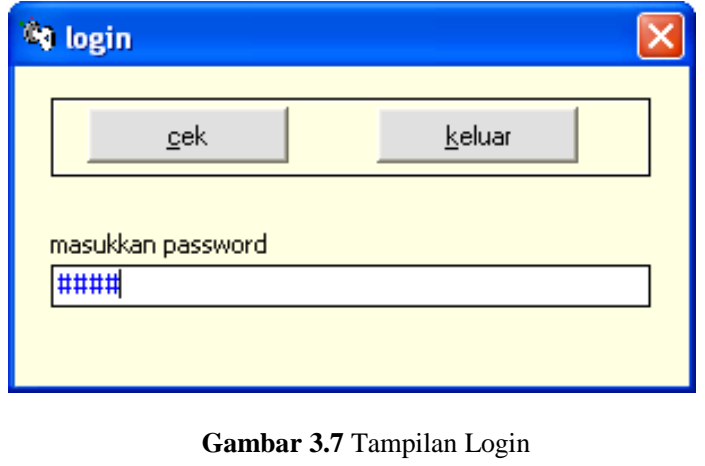

\section{Menu Utama}

Pada menu utama terdapat empat submenu menu utama, yaitu master, transaksi, laporan, dan selesai. Operator dapat memilih submenu yang ada dengan cara mengkliknya. Adapun tampilan menu utama seperti gambar berikut ini.

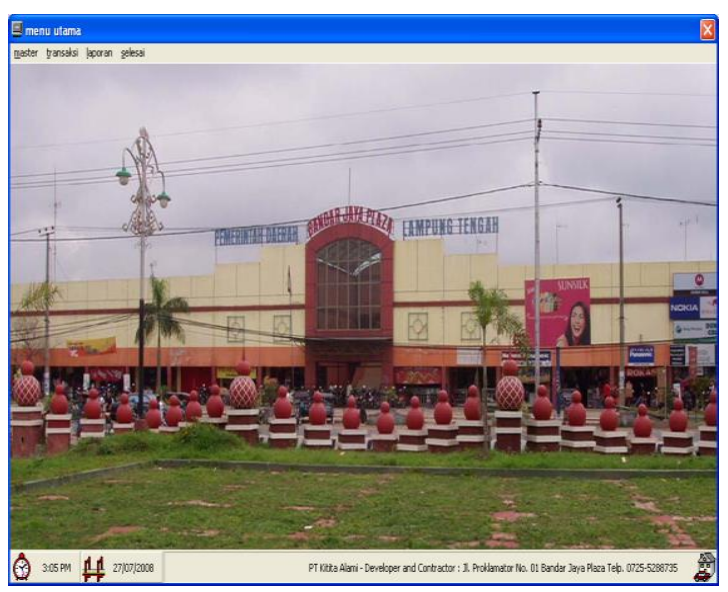

Gambar 3.8 Tampilan Menu Utama 


\section{Program Lokasi}

Setelah tampilan program lokasi aktif, operator memilih blok dan nomor blok pada isian yang tersedia dan secara otomatis kode lokasi akan ditampilkan. Jika kode lokasi tersebut belum ada pada database, operator memasukkan ukuran lokasi, luas, tipe kavling, dan harga kemudian mengklik tombol simpan untuk menyimpannya. Dan jika kode lokasi tersebut ada pada database, secara otomatis ditampilkan data ukuran lokasi, luas, tipe kavling, dan harga. Untuk mengubah data, operator langsung mengganti data yang telah ditampilkan tersebut dan mengklik tombol ubah atau mengklik tombol hapus untuk menghapus data. Tampilan program lokasi ini seperti pada gambar berikut ini.

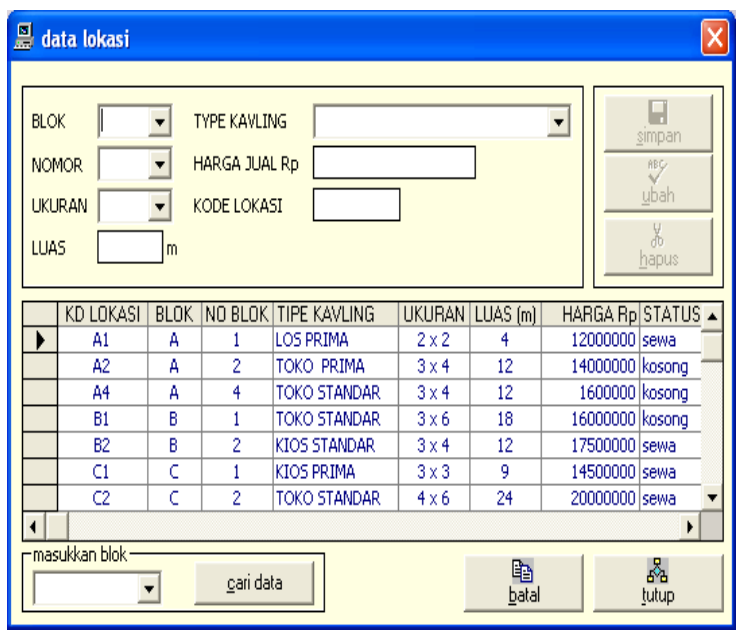

Gambar 3.9 Tampilan Program Lokasi

\section{Program Angsuran}

Program angsuran menampilkan tanggal sesuai dengan tanggal komputer, dan nomor angsuran ditampilkan terurut berdasarkan urutan tahun dan bulan komputer secara otomatis. Untuk menambah data, operator memilih blok dan nomor blok pada isian yang tersedia dan secara otomatis kode lokasi, tipe kavling, harga, nomor registrasi, nama konsumen, sisa pembayara, angsuran ke, dan jumlah angsurannya kemudian mengklik tombol simpan, selanjutnya akan ditampilkan bukti pembayaran seperti Gambar 4.9.

Jika operator akan memperbaiki data, operator memasukkan nomor angsuran yang telah ada pada database dan akan ditampilkan data angsuran yang telah disimpan sebelumnya. Untuk mengubah data, operator langsung mengganti data yang telah ditampilkan tersebut dan mengklik tombol ubah, dan untuk menghapus data, operator dapat mengklik tombol hapus.

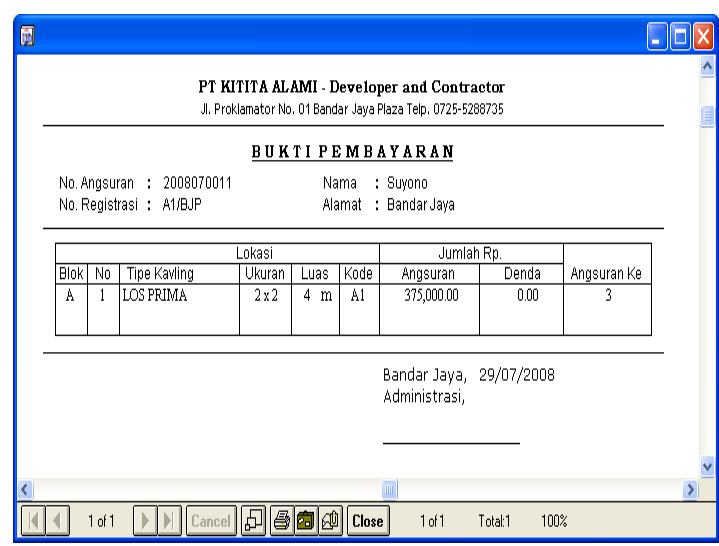

Gambar 3.10 Tampilan Program Angsuran

\section{Submenu Laporan}

Pada submenu laporan terdapat laporan data lokasi, konsumen, dan angsuran. Untuk menampilkan program tersebut operator dapat mengklik pada tulisan program yang dimaksud atau menggunakan shortcut.

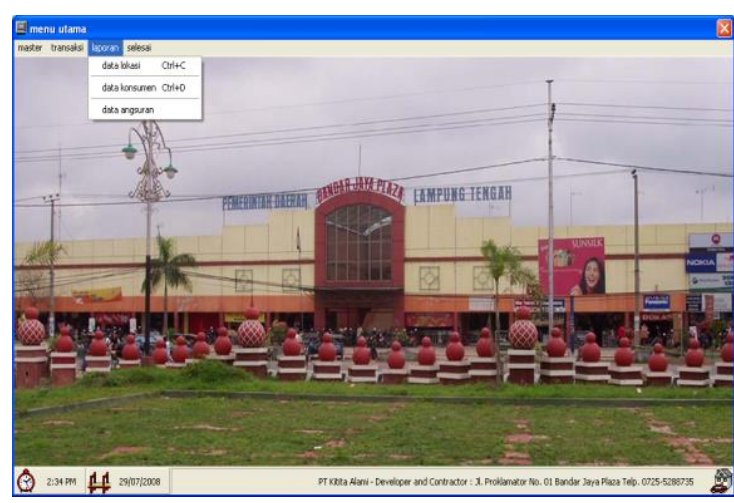

Gambar 3.11 Tampilan Submenu Laporan

\section{Laporan Data Lokasi}

Contoh hasil laporan data lokasi 


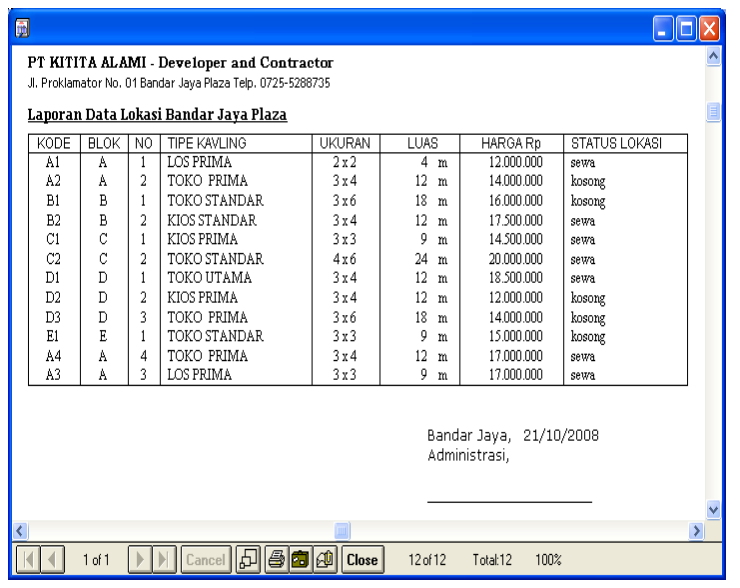

Gambar 3.12 Tampilan Laporan Data Lokasi

\section{Laporan Data Konsumen}

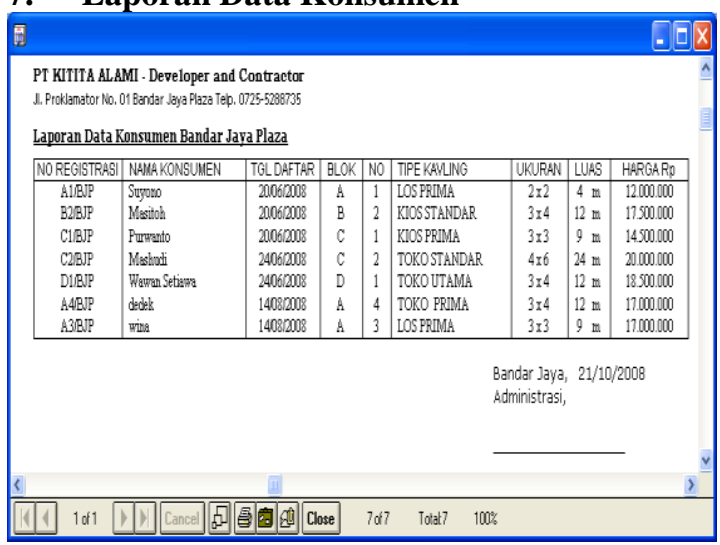

Gambar 3.13 Tampilan Laporan Data Konsumen

\section{Tampilan Laporan data Angsuran Bulanan}

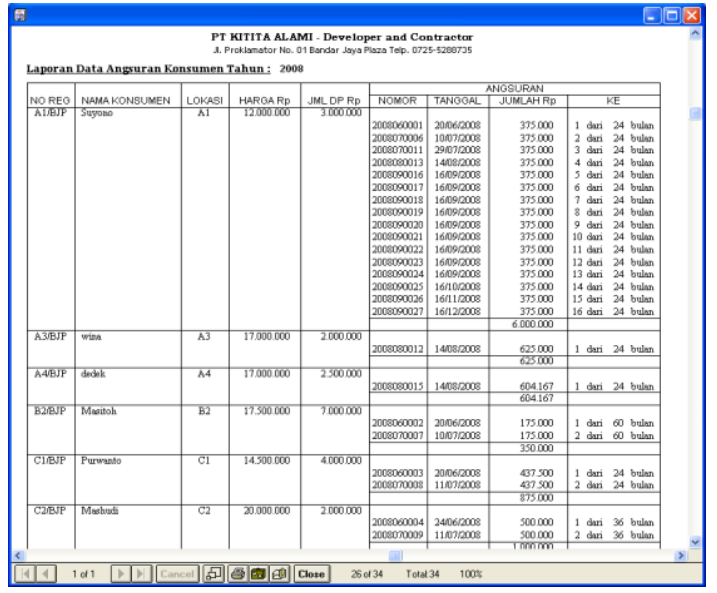

Gambar 3.14 Tampilan Laporan Data Angsuran Bulanan

\section{KESIMPULAN DAN SARAN}

\section{a. Kesimpulan}

Berdasarkan hasil dan pembahasan, kesimpulan dari laporan ini sebagai berikut.

1. Sistem pembayaran angsuran PT Kitita Alami Kantor Cabang Bandarjaya yang berjalan, dicatat pada kertas dan bukti transaksi. Hasil laporan diperoleh dengan merekap kembali bukti-bukti transaksi tersebut setiap hari oleh karyawan.

2. Perancangan dan pembuatan sistem informasi ini menggunakan Microsoft Visual Basic 6, Microsoft Access database, dan Crystal Report untuk pembuatan laporan. Penggunaan software tersebut, menghasilkan program aplikasi yang mudah digunakan oleh user dan fasilitas keamanan program (password).

3. Sistem informasi ini memiliki fasilitas untuk proses manipulasi data seperti penambahan, perbaikan, hapus data, dan pencarian data yang mudah dioperasikan oleh operator. Sedangkan laporan pembayaran angsuran dapat dengan mudah dan cepat diperoleh, sehingga memudahkan perusahaan dalam mengontrol pembayaran konsumen dan transaksi masuknya kas.

b. Saran berikut.

Saran penulis pada laporan ini sebagai

1. PT Kitita Alami Kantor Cabang Bandarjaya diharapkan dapat mengimplementasikan sistem informasi ini untuk memudahkan pekerjaan karyawan dan mempercepat pembuatan laporan angsuran konsumen.

2. Sistem informasi ini perlu dipertimbangkan menjadi sistem client server, sehingga memudahkan pembagian pekerjaan karyawan pada setiap divisi. Dan diharapkan dapat mengintegrasikan sistem administrasi lainnya, seperti kepegawaian dan penggajian karyawan

\section{DAFTAR PUSTAKA}

1. Fathansyah, 2002, Basis Data, Informatika, Bandung.

2. Hartono, Jogiyanto. 2001, Analisis \& Desain Sistem Informasi Pendekatan Terstruktur Teori dan Praktek Aplikasi Bisnis, Andi Offset, Yogyakarta. 
3. Kurniadi, Adi. 2000, Pemrograman Microsoft Visual Basic 6.0, PT. Elex Media Komputindo, Jakarta.

4. Leman, 1997, Metodologi Pengembangan Sistem Informasi, PT. Elex Media Komputindo, Jakarta.

5. LPKBM Madcoms Madiun, 2000, Panduan Lengkap Microsoft Access, Andi Offset, Yogyakarta.

6. Madcoms, 2002, Database Visual Basic 6.0 dangan Crystal Report, Andi Offset, Yogyakarta.

7. M. Agus J. Alam. 2000, Manajemen Database dengan Microsoft Visual Basic 6.0. PT. Elex Media Komputindo. Jakarta.

8. Mulyadi, 2001, Sistem Akutansi, Salemba Empat, Jakarta.

9. Tim. 2006, Panduan Penyusunan dan Penulisan Karya Ilmiah, STMIK Teknokrat, Bandar Lampung. 